DOI https://doi.org/10.18551/rjoas.2018-08.43

\title{
FACTORS DRIVING REMITTANCES BY MINANGKABAU'S MIGRANTS TO SENDING HOUSEHOLDS IN RURAL AREAS
}

\author{
Ismawati lis* \\ Doctoral Program of Agriculture,University of Brawijaya, Indonesia \\ Mustadjab Muslich, Hanani Nuhfil, Syafrial \\ Faculty of Agriculture, University of Brawijaya, Indonesia \\ *E-mail: iesmawati08@gmail.com
}

\begin{abstract}
Minangkabau culture is characterized by a matrilineal family system and high level of migration. The contribution of Minangkabau migrants to rural origins and household left behind is generally very high. However, there is currently limited empirical research on this issues especially to paddy farm households in rural areas. This article emphasizes what decision to remit is intensely associated to individual migrant, farm household and social group characteristics. Using farm households survey data from three villages in West Sumatera, our results lend support that remittances are sending to farm households with low levels of welfare. Futhermore, individual characteristics such as gender and migrant expenditure are influential in remitting patterns. In addition, no differ between clan groups of migrants. These results indicate primary driver of Minangkabau migrants in sending remittances is altruism. Understanding the sending of remittances behavior is crucial for rural areas to improve these potential capital transfer for more sustainable agricultural development programme.
\end{abstract}

\section{KEY WORDS}

Mirgation, remittances, rural, farm, households.

Migration is a global phenomenon, the number of migrant is generally presumed to be growing. Indonesia as the island country has a considerable level of mobility. The Minangkabau are one ethnics in Indonesia has a high level of migration. Minangkabau's has experienced high migration outflows and remittances inflows in West Sumatera. Migrations of the Minangkabau is a culture that has become the rite de passage, especially for young men (Naim, 1979). Meanwhile, Murad (1978) said that merantau is a socially and culturally institutionalised pattern of migration in Minangkabau society. Unsurprisingly Socio-economic factors became one of the dominant factors that drive migration Minangkabau ethnic (Murad, 1978; Kato, 2005)..

Although it was far from the area of origin, do not reduce the bond with the family and indigenous community in the village. Minangkabau migrants are known to have a high spirit of Philanthropy (Addiarrahman, 2013) and concern over the welfare of the region of origin is also very high (Kato, 1982). According to Murad (1978), migrants visit the region to meet their obligations and duties in the family at the same time contribute to sustainable development. For example, if there are construction projects such as building schools, clinics or mosques, the migrants send money or building materials.

A large empirical study was recently the impact of remittances on increased development and welfare, both global level as well as the household. Remittances are a source of sustainable external capital can reduce poverty in developing countries (Mohapatra et al., 2010; Adams and Page, 2005; SOPEMI, 2006). Remittance also contributes to welfare through increased income, savings and investment (Ratha,2003). On the side of the household, remittances can be input to the decision-making process, influencing the supply of labor, self-employment, and fertility (Funkhouser, 1995). Remittances could reduce the 
income risk of the family left behind by diversifiying the source of income. (Stark, 1991; Agarwal and Horowitz, 2002).

Remittances can increase the agricultural output ( Huy, 2016). Although migration reduces the availability of labor in agriculture and resulted in the loss of the crops, but can be compensated through the reinvestment of remittances. In the Philippines, remittances positive effect on increasing the ownership of household goods, time for entrepreneurship and investment in the sectors of transport, communications and manufacturing (The,2008). While in Guatemala, remittances are used to improve the household human capital such as schools and investment in housing (Adams and Cuecuecha, 2010)

Recipients of remittances in Indonesia more use for the consumption of basic necessities. (Adams and Cuecuecha, 2010). High poverty rates and low levels of remittances is alleged to be the cause of such behavior. Similar conditions occurred in Tajikistan, where remittances have significantly improved the level of household consumption however negatively impact spending on investment (Clément 2011).

It is important to note that remittances can give a negative or positive impact on household welfare in the area of origin. The effect of remittances on well-being varies with the economic characteristics of migrants, migration experience and diversity of arrangements. For instance, migrants welfare may be positively affected by transferring money to the family left behind (Akay et.al, 2012). In the context of West Sumatera, there are a unique aspects of Minangkabau culture, such as a strong moral obligation to care for family left behind. The contribution of Minangkabau migrants is not only for family, but also for the benefit of the development of their home villages (Murad, 1978). Brown and Walker (1995) said that migrants can be motivated to remit for reasons of saving and investment in their country origin, including investment in human capital formation of the next generation. However, there is currently limited empirical research on Minangkabau's behaviour to sending remittances, especially on paddy farm households.

Thus, it is crucial to identify what factors pushing migrants send remittances to his family in the rural of origin. This research aims to analyze the effect of the characteristics of the migrants and household origin against the level of remittances sent by migrants in the Minangkabau ethnic. The target of this research is specifically intended for paddy farm households, considering most of the migrants come from rural-based agriculture.

\section{LITERATURE REVIEW}

Remittances sent in the household in the region ranged from $10-30 \%$ of the income of migrants (Stark,1978). Stepick and Portes (1989) report, the number of remittances sent by Haitians to the region reached $39 \%$. Empirical studies show that the amount and pattern of delivery of remittances vary widely depending on the type of migrant origin, the income level of the family and the level of remittances received. What factors encourage migrant sending remittances to families in the region of origin in question the researchers. Considering each individual migrant and regional origin of the differences in the conditions and characteristics.

Willingness to remit really depends on many factors such as the migrant's ability, motivation, duration of migration and the conditions of the family left behind. Stark and Lucas (1988) said that to understand how patterns of remittances from rural to urban needed knowledge of the contractual agreement between the migrants with the family. Based on several studies about the factors that encourage the willingness to remit there are two themes: first studies related to the motivation of the migrant and the second relates to the characteristics of the migrant and the household left behind.

The analysis of the variation in willingness to remit can be approached from different frames of views. A basic motivation of a willingness to remit may be altruistic feelings towards the household left behind. In the Becker's model the migrant derives positive utility from the consumption by the family. Consequently migrant cares about poverty, welfare, shocks, etc of household left behind and sends remittances. Research on the motivation of sending remittances was first expressed by Lucas and Stark (1985) which stated that the delivery of remittances in influence by the difference of motivation. Types of motivation were 
split into three, namely: 1) pure altruism, 2) pure self-interest and 3). The enlightened selfinterest. Some type of agreement the agreement-related motivation sending remittances between migrants and the household left behind are divided into categories such as 1) coinsurance, 2) Loan repayment and 3) exchange motives.

Deppo (2014) stated that pure altruistic became the dominant factor in motivating migrant remittances sent to Guiana region. According to Funkhouser, (1995) the migrant remittances increase if income increases and altruism. While Batista and Umblijs (2016) found that migrants who have a risk of high wages and strong financial resources with the migrants will have a high motivation to post remittances. This phenomenon is known by the term self-insurance. The existence of the insurance motive, means that remittances play a key role in the improvement of welfare of households (Nnyanzi, 2016)

In addition to the altruistic motivation, another important factor affecting migrants send remittances are migrant and household left behind characteristics. Funkhouser (1995) states relations with migrant household becomes important in encouraging migrants to send remittances. Migrants who have parents, siblings, wife, and children in the regions of origin tend to send larger remittances. In addition, the migrant characteristics such as education, gender, type of work, duration of migration and the amount of income also determine the level of remittances sent.

Hagen-Zanker and Siegel (2007) finding that the causes and patterns of migration influence the remitting behaviour. Geographical location, economic possibilities, individual and household characteristics that influence remitting patterns. Migrant age, sex, marital status, education, household income, wellbeing and migration patterns are influential in determining the amount of remitances received. Males are the majority of migrant in Albania and Moldova. In Albania, higher amounts are sent to the poorer households. Albanian men send higher amounts of remittances probably due to cultural practice, while in Moldova women send higher amounts. In another study Brown and Ahlburg (1999) said a dominant characteristic of migrantion in the Pacific is the family. Futhermore, Piracha and Saraogi (2011) suggest that combination of household and migrant characterictics and some community level variables are the key elements in explaining the remittances behaviour in Moldova.

\section{METHODS OF RESEARCH}

The data used in this study come from paddy farm household survey questionnaires in Sulit Air, Sungai Tarab, and Koto Baru villages. The respondents of the research were that paddy farmer. Information of migrant came from farm households were interviewed. The amount of the paddy farm households with migrant 163 people, without migrant 75 people and migrants to 371 people. The survey collected information on paddy farm household characteristics, asset endowment, non farm activities and migran's data. Data analysis model of migrants intended to find out the factors that influence variation remittances to sending household left behind

Logit regression is used for the analysis of the driving factors for migrants to send remittances. The dependent variable $(\mathrm{Y})$ are categorikal i.e. the decision to send remittances: yes (1) and no (0). The decision shows the probability of sending remittances $(P)$ and not send remittances (P-1) are expressed in the following formula:

$$
\begin{gathered}
P=E\left(Y-\frac{1}{x}\right)=\frac{1}{1+e^{-z}} \\
Z=\beta_{0}+\beta_{1} X_{1} \\
1-P=\frac{e^{-z}}{1+e^{-z}}
\end{gathered}
$$

The above equations are molded into the next equation Odd Ratio with the following form: 


$$
\frac{P}{1-P}=\left\lfloor\frac{\frac{1}{1+e^{-z}}}{\frac{e^{-z}}{1+e^{-z}}}\right\rfloor=\frac{1}{e^{-z}}=e^{-z}
$$

Factors driving the migrant's decision to send remittances are obtained through the logit model as follows:

$$
Y=\beta 0+\beta 1 X_{1-14}+\beta D 1 X D 1+\beta D 2 X D 2+e
$$

Where:

$\mathrm{X} 1$ = farm HH Income, $\mathrm{X} 2$ = Villages Location;

$\mathrm{X} 3$ = Land size, $\mathrm{X} 4$ = farm $\mathrm{HH}$ size;

$\mathrm{X} 5$ = schoolchild, $\mathrm{X} 6=\mathrm{HH}$ Head years of school;

X7 = HH Head age, X8 = Migrant gender;

D1 = Ethnics Dummy, X9 = Migrant years of school;

$\mathrm{X} 10=$ Migrant age, $\mathrm{X} 12=$ Migrate duration;

D2=Marital status of migrant (dummy), X13= type of destination areas;

$\mathrm{X} 14=$ The destination minimum wage, $\mathrm{X} 11=$ Migrant $\mathrm{HH}$ size .

\section{RESULTS AND DISCUSSION}

The Descriptive Statistics. Paddy farm households who have the largest migration of members came from the village of Sulit Air (40.97\%). However the household in the villages of Koto Baru has the average number of members who go the migration more than other villages (Table 1). The village of Sulit Air is known as an area with high levels of mobility in West Sumatra. Sulit Air is located in ridges and hill slopes; dry, barren and hilly, causing less developed agricultural sector. It is becoming one of the driving population Sulit Air migrate. The same situation also applies to the village of Koto Baru. Whereas Sungai Tarab, as the village centers of agriculture especially Paddy, has more arable land. The village is a major producer of paddy. So population migrate less than any other villages.

Table 1 - The Distribution Of Paddy Farm Households Members Migrating

\begin{tabular}{llll}
\hline Villages & $\mathrm{N}$ & Percentage & Average of Migrants \\
\hline Sungai Tarab & 88 & 23,72 & 1,69 \\
Sulit Air & 152 & 40,97 & 2,33 \\
Koto Baru & 131 & 35,31 & 2,85 \\
\hline Total & 371 & 100,00 & \\
\hline
\end{tabular}

Source: Field survey, 2017.

A list of the characteristic of paddy farm households with and without migrant in Table 2. The subset of data obtained for this study focuses on the land tenure, demographic data and household income. Paddy farm households with migrants tend to be of less welfare (based on paddy land size and total income per year) and less educated than household without migrants.

Table 2 - Characteristics of Paddy Farm Households

\begin{tabular}{lll}
\hline Characteristics & $\mathrm{HH}$ with at least one migrant & HH without migrant \\
\hline Paddy land size (hectares) & 0,43 & 0,61 \\
Household Size & 4,12 & 4,52 \\
Number of School children & 1,10 & 1,45 \\
HH Head years of education & 7,67 & 8,93 \\
HH Head age & 56,96 & 51,04 \\
Average HH Total Income & 30.598 .119 & 43.496 .095 \\
\hline
\end{tabular}

Source: Field survey, 2017. 
Based on paddy farm households characteristics, the classification of the income source came from multiemployment, i.e. on farm, off farm, non farm, government grant, migrant organizations grants, remittances and other sources. The highest income share of paddy farm households is still derived from agriculture (33.91 percent). Agricultural sector especially paddy cultivation is still a major source of livelihoods for households in rural West Sumatera (Afrizal et al., 2017). Non-farm activities are also one of the sources of income is large, reaching 25 percent. While remittances contribute 9.55 percent of total income (see Table 3).

Table 3 - Paddy farm Households Total Income Distribution

\begin{tabular}{lll}
\hline Sources & Income (IDR) & Percentage \\
\hline On farm & 10.376 .413 & 33,91 \\
Off-Farm & 5.199 .619 & 16,99 \\
Non-Farm & 7.950 .239 & 25,98 \\
Goverment grants & 465.585 & 1,52 \\
Migrant organization grants & 61.534 & 0,20 \\
Remittances & 3.623 .006 & 9,55 \\
Other sources & 2.921 .723 & 11,84 \\
\hline Total income & 30.598 .119 & 100 \\
\hline
\end{tabular}

Source: Field survey, 2017.

Futhermore, Table 4 showing the characteristics of migrants. Paddy Farm household members who migrate are dominated by male sex $(62 \%)$ and married $(74 \%)$. The matrilineal culture in Minangkabau has encouraged young Minang men to migrate (the age 20-35 years whilst $61 \%$ ). Refers to Murad (1978), matrilineal culture is often to compel Minang man in disadventaged kinship positions in their homeland to migration.

Table 4 - Characteristics of Migrants

\begin{tabular}{lll}
\hline Characteristics & $\mathrm{N}$ & Percentage \\
\hline Male & 230 & 62 \\
Female & 141 & 38 \\
Married & 276 & 74 \\
Unmarried/divorced, widowed & 95 & 26 \\
\hline Age & & \\
$20-35$ & 225 & 61 \\
$36-50$ & 125 & 33 \\
$51-65$ & 19 & 5,5 \\
$>65$ & 2 & 0,5 \\
\hline Education: & & \\
No formal schooling/incomplete & 16 & 4 \\
Elementary school & 53 & 14 \\
Junior high school & 109 & 29 \\
Senior high school & 171 & 46 \\
colleges & 22 & 6 \\
\hline Duration of Migration: & & \\
$<1$ year & 12 & 3 \\
$1-5$ years & 123 & 33 \\
6-10 years & 26 \\
$11-15$ years & 98 & 14 \\
$16-20$ years & 52 & 11 \\
$>20$ years & 42 & 12 \\
\hline Destination areas: & 44 & 12 \\
West Sumatera & & 31 \\
Jakarta/the capital city of Indonesia & & 1 \\
International & & 57 \\
Inter-provincial & 43 & \\
\hline
\end{tabular}

Source: Field survey, 2017.

According to the data, only $4 \%$ of migrants are illiterate or had no more than elementary school education and $14 \%$ have reached the level of junior high school. The 
proportion of migrants who have reached the senior high school and colleges is $52 \%$. It is indicates that migrants from rural areas in West Sumatera more educated than their head households in homeland.

Regarding the choosen of areas destination, more than $31 \%$ of migrants lived in Jakarta, the capital city of Indonesia, $12 \%$ migrate in West Sumatera Province and only $1 \%$ go to overseas. However the majority of migrants $(57 \%)$ widespread of inter-provincial in Indonesia. It can be seen that the largest number of Minang people from rural areas in the district have migrant to Jakarta. Unsurprisingly that pletora Indonesian migrants had chosen Jakarta as destination area . Refers to Murad (1978), that Jakarta was the single most prefered province for Minagkabau migrants and secondly were chosen the neighbouring provinces such as Riau, Jambi, Palembang and North Sumatera. International migration is rarely chosen by the Minangkabau ethnic group who come from the rural areas.

There seem to be interesting that about $64 \%$ of migrants have stayed in destination areas more than 5 years. Although originally the Minang ethnic migration is commuter and circular, there is now a permanent tendency. The data show that the duration of migration is $97 \%$ permanent. The results of this study were supported by Maude (1979), that a half of all medium and long-term migrants from West Sumatera are now permanent migrants.

Characteristics of migrants behavior to sending remittances are drawing on Table 5. The total number of migrants who sending remittances to household left behind was 337 person or $91 \%$ from all data. It is interesting to noted that Minang migrants from rural areas predominantly responsible to their family in homeland. According to Addiarrahman (2013) and Kato (2005) were said that Minangkabau migrants are known to have a high spirit of Philanthropy and concern over the welfare of the region of origin is also very high (Kato, 1982). More than $52 \%$ of migrants send remittances, and the range of average transferred amount exceeds IDR 500.000-1.500.000 per year.

Table 5 - Characteristics of Remittances Behavior

\begin{tabular}{lll}
\hline Characteristics & $\mathrm{N}$ & Percentage \\
\hline a. Sending remittances (at least 1x/year) & 337 & 91 \\
Yes & 34 & 9 \\
No & 371 & 100 \\
\hline Sum & \multicolumn{3}{|}{} \\
\hline b. Channels of I Remittances & 271 & 81 \\
Bank & 13 & 4 \\
Post office & 14 & 4 \\
Family/friendship & 39 & 12 \\
Visit homeland & \multicolumn{3}{|}{} \\
\hline c. Remittances (IDR) & 95 & 28 \\
$>500.000$ & 176 & 52 \\
$500.000-1.500 .000$ & 34 & 10 \\
$1.500 .001-2.500 .000$ & 7 & 2 \\
$2.500 .001-3.500 .000$ & 25 & 7 \\
$>3.500 .000$ & \multicolumn{2}{l}{} \\
\hline
\end{tabular}

Source: Field survey, 2017.

There are four payment channel to sending remittances to relatives households left behind: bank servics $(81 \%)$, post office $(4 \%)$, via family/friends $(4 \%)$ and carrying cash when travelling back home (12\%). Overall, the majority Minangkabau migrants are likely to use formal channels and bank services are generally preferred for it. Kosse and Vermeulen (2014) find that higher educated migrants are less likely to use informal channels or to carry cash themselves. Drawing on data (Table 5) , $46 \%$ of migrants were high school graduated and $6 \%$ from colleges. At the same time, however, kinship functions between migrants and family system still guarded. There are $12 \%$ migrants visit their homeland in order to carry cash remittances.

Results of The Logit Model. The model was tested using the Likelihood Ratio Test. This model according to statistics $G$ spread in Chi-Squared (x2.). The estimates of equations are shown in Table 4. The value of the Likelihood Ratio obtained 23.7388 with p-value 0.0954 . 
The conclusion is the entire model can explain or predict the decision of Minangkabau's migrant send remittances. migrant opportunities send remittances amounted to 72.9 percent. The Wald test results are shown by the coefficient value of $\beta$. Of the sixteen predictor variables, only four variables had a significant effect on the decision to send remittance.

Table 6 - Logit Regression Analysis of determinants of Remittances to Paddy Farm Households

\begin{tabular}{lllll}
\hline Predictor Variables & Parameter $\beta$ & Wald & Significance & Exp $(\beta)$ \\
\hline Constant & -0.9339 & 0.2267 & 0.6340 & 0.0366 \\
Income & $-44 \mathrm{E}-11$ & 0.0008 & 0.9775 & 0.8370 \\
Paddy land size & -2.2122 & 6.2073 & 0.0127 & 0.7394 \\
Household Size & 0.0117 & 0.0058 & 0.9394 & 0.7073 \\
Number of School children & 0.1991 & 0.5520 & 0.4575 & 0.1611 \\
HH Head years of education & 0.0496 & 0.4381 & 0.5080 & 0.7091 \\
HH Head age & 0.0182 & 0.7672 & 0.3811 & 0.2076 \\
Gender of migrant & -0.8709 & 4.3698 & 0.0366 & 0.0372 \\
Ethnics dummy & -0.0526 & 0.0423 & 0.8370 & 0.419 \\
Migrant years of education & 0.0630 & 0.6517 & 0.4195 & 0.949 \\
Migrant age & 0.0104 & 0.1107 & 0.7394 & 1.065 \\
Marital status of the migrant & -0.1265 & 0.1410 & 0.7073 & 1.010 \\
HH migrant size & -0.2645 & 1.9636 & 0.1611 & 0.881 \\
Duration of migration & 0.0108 & 0.1392 & 0.7091 & 0.768 \\
Villages location & -0.5777 & 3.0839 & 0.0791 & 0.4195 \\
Type of Destination Area & 0.6027 & 1.5880 & 0.2076 & 1.011 \\
The destination minimum wages & $-1.1 \mathrm{E}-6$ & 4.3419 & 0.0372 & 1.827 \\
\hline Likelihood Ratio (Chi-Square) $=23.7388 ;$ Pr>ChiSq $=0.0954$ & & & \\
Percent Concordant & 72,9 & Somers'D & & 0,465 \\
Percent Discordant & 26,4 & Gamma & & 0,468 \\
Percent Tied & 0,7 & Tau-a & & 0,076 \\
\hline
\end{tabular}

Characteristics of paddy farm households variables that have a significant effect, only land tenure. Estimated parameter value -2.2122 means that migrants have the probability to send remittances to households with less land areas. The important findings for this research, that factors driving to send remittances to peasant households is intensely associated to the ownership of agricultural land. Because the land tenure level will determine the amount of paddy production. The more land leading to increase in cultivation and agricultural production.. Migrants will send remittances to less prosperous households, because of the small production capacity of paddy, due to the narrow land area. In other words inequality due more less access to land has driving Minang people to migrate. In contrast, in term of peasant household size, the number of school children and the level of income does not affect the desire Minangkabau migrants to send remittances. Those variables do not hold for the probability to sending remittances, but it is found by most authors for the level of remittances.

The condition of rural village infrastructure affects the probability of migrants sending remittances. The estimated value of -0.577 indicates that migrants from marginal regions have an opportunity to send remittances. Based on the odd ratio, it is seen that migrants from Sulit Air Village have the opportunity to send remittances 0.419 times less than migrants from Koto Baru and Sungai tarab villages. As previously described Sulit Air is located in the ridges and hills slopes, causing the villagers to have high mobility. The marginal condition of the village also encourages migrants to send remittances to their households left behind.

Variable the migrant characteristic that affects the probability of sending remittance is the gender dummy (male $=1$, female $=0$ ). The negative parameters indicate the probability of male migrants to send remittances 0.0372 percent less than female migrants. The results of this analysis fit the research of Lucas and Stark (1985) which states that for the same job women have a tendency to send remittances larger than men. A study by Osaki (2003) shows that female out-migrants are 1,2 times more likely than male to remit cash or goods. Due the odds ratio is relatively small, so the opportunity to send remittance by gender cannot be concluded only dominated by the female gender. Because some studies have also shown 
that male migrants have a tendency to send remittances larger than women, given that more men work more than women (Okay, 2008) .

The Regional Minimum Wage (RMW) predictor variable has a negative relationship with the opportunity of migrant to send remittance, indicated by the estimated value of $-1.1 \mathrm{E}$ 6 . Based on the odds ratio, it is known that migrants living in areas with large UMR levels have an opportunity to send 1,827 remittances less than those living in areas with low RMW levelsRMW city of Jakarta in 2016 amounting to RP.3.100.000, is the greatest wage value compared to other destination UMR destination migrants. In theory, migrants living in areas with larger UMR have a tendency to send larger remittances. However, this study yielded the opposite finding. The high cost of living in the capital is thought to be the cause of this phenomenon.

Overall of the predictor variables, only 28 percent of the variables had a significant effect on the probability of migrants sending remittances. The limitations of the variable dimensions used in this study are thought to be the cause of the many insignificant variables. As described earlier, this study uses only general demographic variables. Whereas the opportunity for migrants to send remittances is not only influenced by the characteristics of families and migrants. Many other aspects have been empirically proven to contribute much to motivating migrants to send remittances. One of the well-known theories is the theory of altruism introduced by Stark and Bloom (1985) which states that responsibility for household left behind becomes a great motivation for migrants to send remittances.

In this context, we suggest that altruism is the most factors that encourage Minang migrants to sending money to family left behind. This is reinforced by the statement of Auda (1978) which states that migrant Minang has a high sense of responsibility towards family and hometown. Lucas and Stark (1985) argue that, if migrants are motivated by altruism, remittances should be positively related to the migrants' own income and negatively related to the family's income. According to previously of exposition, that remittances are sending to farm households with low levels of welfare. Unfortunately, this issue (altruism) did not be part in our study.

\section{CONCLUSION}

The empirical results of this study reveals that Minangkabau's migrants from rural areas has been kept a'culture of mobility' and fulfillment obligation to their family in rural areas. Formal channels such as bank and post office more prefered for Minang's migrants to sending money. We also find that decision to remit is affected by both households and migrants characteristics combined with home and host land conditions. Migrants have more the probability to send remittances to paddy farm households with less land and reside in marginal rural areas. On the migrant side, female migrants have a greater probability of sending remittances than male migrants. The standard cost of living in the destination areas also affects the migrant's drive to send remittances. If migrants expenditure increase, migrants impultion to remit will decrease.

An important findings from this study is remittances are generally sending to paddy farm households with low levels of welfare and reside in marginal villages. Level of financial migrants determine behavior remittances. In order to determine the Minang's migrants motives of remittances transfers to rural origins more clearly, future research and more detailed information on households and migrants are needed.

\section{ACKNOWLEDGEMENTS}

We would like to express my special thanks are due to 1) the Ministry of Research, Technology and Higher Education (KEMENRISTEKDIKTI) of The Republic of Indonesia for funding in Doctoral Grand in 2018 with number of agreement contract: 048/SP2H/LT/DRPM/2018; 2) to our Promotor Team in Program doctoral University of Brawijaya (Prof.Muslich Mustadjab, Prof.Nuhfil Hanani and Dr. Syafrial) and 3) Research institutes and community services in State Agricultural Polytechnic of Payakumbuh. 


\section{REFERENCES}

1. Adams, R.H and Cuecuecha,A. 2010a. Remittances, household expenditure and investment in Guatemala. World Development Vol.38(11), pp.1626-1641.

2. Adams,R.H.Jr dan A.Cuecuecha. (2010b.). The Economic Impact of International Remittances on Proverty and Household Consumption and Investment in Indonesia. Policy Research Working Paper No. 5433

3. Adam, R and Page.J. (2005) Do international migration and Remittances reduces poverty in developing countries? World Development col 33(10), pp.1645-1669.

4. Addiarrahman. (2013). Baragiah ka Kampuang: Spiril Filantripis Perantau Sulit Air. Turast: Jurnal Penelitian dan Pengabdian Vol.1 No.1

5. Afrizal, Roni., Rizkiyah.Noor and Ismawati.lis. (2017). Impact of Minangkabau's out migration: Merantau to labor allocation in West Sumatera-Indonesia. Russian Journal of Agricultural and Socio-Economics Sciences (RJOAS). Vo.10(70).

6. Agarwal,R and Horowitz,A.W. (2002). Are international remittances altruism or insurance? Evidence from Guyana using multiple-immigrant households. World Development, Vol.30 (11),pp. 2033-2044.

7. Akay,A., C.Guilietti., Juan D. Robalino and Klaus F. Zimmermann. (2012). Remittances and Well-Being among Rural-to-urban migrants in China. IZA DP No.6631.

8. Batista,C and J.Umblijs. (2016). Do migrants send remittances as a way of selfinsurance?. Oxford Economic Paper, Vol.68(1), pp.103-130.

9. Brown,R.P.C. and Walker,A. (1995). Migrants and their remittances results of a household survey of Tongans and Western Samoans in Sydney. Pacific Studies Monograph. No.17. Centre for South Pacific Studies. University of New South Wales, Sydney.

10. Brown, R.P.C and Ahlburg,D.A. (1999). Remittances in South Pacific. International Journal of Social Economics. Vol.26 Issues:1/2/3,pp.325-344.

11. Clément, Michael A. (2011). Economics and emigration:trillion-dollar bills on the sidewalk?.Journal of economic Perspective,Vol.25(3), pp.83-106.

12. Depoo,Tilokie. (2014). Guyanese remittance motivations: Altruistic? International Journal of Social Economics Vol.41 (3). pp.201-212.

13. Funkhouser,E. (1995). Remittances from International Migration: A comparison of El Savador and Nicaragua. The Review of Economics and Statistics. Vol.77 No.1

14. Hagen,J., Zanker dan M Siegel. (2007). A Critical Discussion of The Motivations to Remit in Albania and Moldova. Working Paper. Maastricht Graduate School of Governance. Maastricht University.

15. Huri,Irdam. (2006). Filantropi Kaum Perantau: Studi Kasus Kedermawanan Sosial Organisasi Perantau Sulit Air Sepakat (SAS) Kabupaten Solok, Sumatera Barat. Piramedia, Depok.

16. Huy,H.T and W.Nonneman. (2016) . Economics effects of labor migration on agricultural production of farm households in the Mekong River Delta region of Vietnam. Asian and Pacific Migration Journal Vol.25(1), pp.3-21.

17. Kato,Tsuyoshi. (2005). Adat Minangkabau dan Merantau; Dalam Perspektif Sejarah. Balai Pustaka. Jakarta

18. (1982). Matriliny and Migration: Evolving Minangkabau Traditions in Indonesia. Cornell University Press

19. Kosse,A and R.Vermeulen. ( 2014). Migrants' choice of remittance channel do general payment habits play role? Working Paper Series No.1683. European Central Bank.

20. Lucas,R.E.B. dan O.Stark. (1985). Motivations to Remit: Evidence from Bostwana. Journal of Political Economy, Vol.93, No.5.

21. Mohapatra,S and Ratha,D. (Eds.). (2011). Remittance market in Africa. Washington DC. World Bank. 
22. Murad, Auda. (1978). Merantau: Aspects of Outmigration of the Minangkabau People. Thesis. Australian National University. Canberra. https://openresearchrepository.anu.edu.au/bitstream/1885/117421/4/b11710457_Murad_Auda.pdf

23. Naim,Mochtar. (1979). Merantau: Pola Migrasi Suku Minangkabau. Gadjah Mada University Press.

24. Nnyanzi, John,B. (2016). What drives international remittances to Africa: Altruism, selfinterest or the institutional environment? African Journal of Economic and Management Studies. Vol.7 Issue:3, pp. 397-418

25. Piracha,Matloob and A.Saraogi. (2011). Motivations for Remittances: Evidence from Moldova. IZA DP Np.5467.

26. SOPEMI. (2006). International Migrant remittances and their role in development. International Migrant Outlook SOPEMI. ISBN 92-64-03627-X

27. Ratha,D. (2003). "Workers" Remittances: An Important and Stable Source of External Development Finance. In Global Development Finance 2003. Wahington DC. World Bank.pp.157-175

28. Stark odded. (1978). Economic-Demographic Interactions in Agricultural Development: The Case of Rural-to-urban Migartion. Rome: UN Food and Agriculture Organization.) in order to understand urban-to-rural remittances, it is necessary to understand the migrantfamily contract and its properties

29. Stark, Oded and R.E.B.Lucas. (1988). Migration, remittances, and the Family. Economic Development and Cultural Change. Vol 36 (3). pp. 456-481.

30. Stark,O. (1991). The Migration of Labor. Oxford. Basil Blackwell.

31. Yang,D. (2008). International migration, remittances and household investment: evidence from Philippine Migrants' exchange rate stocks. The Economic Journal, Vol 118,pp.591630.

32. Yue,X. and S.Ng. (1999). Filial Obligation and Expectations in China: Current views from young and old people in Beijing. Asian Journal of Social Psychology Vol 2.No.2,pp. 215226. 